\title{
Magic, Miracles, and the Cultural Evolution of Pauline Christianity
}

\section{Nikki, Nina}

Vandenhoeck \& Ruprecht

2021

Nikki , N 2021, Magic, Miracles, and the Cultural Evolution of Pauline Christianity . in K Valkama \& N Nikki (eds), Magic in the Ancient Eastern Mediterranean : Cognitive, Historical, and Material Perspectives on the Bible and Its Contexts . 1 edn , Mundus Orientis , no. 3 , Vandenhoeck \& Ruprecht , Göttingen , pp. 115-136 . https://doi.org/10.13109/9783666522185.115

http://hdl.handle.net/10138/336961

https://doi.org/10.13109/9783666522185.115

unspecified

acceptedVersion

Downloaded from Helda, University of Helsinki institutional repository.

This is an electronic reprint of the original article.

This reprint may differ from the original in pagination and typographic detail.

Please cite the original version. 


\title{
Magic, Miracles, and the Cultural Evolution of Pauline Christianity
}

\author{
Nina Nikki
}

\section{Introduction}

In Buddhist tradition, Siddhartha Gautama is considered an ordinary man who found spiritual enlightenment through meditation. Despite its emphasis on human effort and the "naturalness" of meditative life, however, Buddhist literature still features miracles extensively. ${ }^{1}$ Miracles are considered to be consequences of the practice of meditation and available to anyone through their own effort. ${ }^{2}$ Many miracles, however, go beyond this: it is told, for example, that even as a baby, a lotus flower would bloom everywhere the Buddha placed his foot.

A similar tension concerning miracles surrounds Islamic prophet Muhammad, who, even though the Qur'an notes emphatically that he is a mere human being, is known for a host of miracles especially in the later biographical Sira literature. ${ }^{3}$ Respected figures of Christian tradition are no exception to this propensity to miraculous enrichment. The New Testament Gospels already depict Jesus as a healer and miracle-maker, and such traditions only become more spectacular with time: in the Infancy Gospel of Thomas, the boy Jesus turns clay birds into real ones (III,1-2). Outside the canonical writings, Jesus's mother Mary, for example, gradually becomes a superhuman figure, along with a multitude of other saints, who perform extraordinary acts from healing to rainmaking and levitation.

The task of this article is to look at the phenomenon of magical enrichment in the strand of Christian tradition that formed around the figure of the Apostle Paul. The article will investigate the ascriptions of magic and miracles to the figure of Paul in the authentic letters of Paul and the Acts, both the canonical and apocryphal ones, and how this development relates to the cultural evolution of Pauline Christianity.

\footnotetext{
${ }^{1}$ The Buddha is told to have performed all kinds of miracles—-for example, feeding a crowd with a bowl of rice, reading minds, flying, and issuing water and fire from his body. See Gethin 2011 for further examples.

${ }^{2}$ Gethin 2011, 219-220.

${ }^{3}$ The Qur'an explicitly denies that Muhammad was a sorcerer (sahir) or a soothsayer (kahin) or that he was possessed by a jinn (Khalidi 2009, 29). See, e.g., 3:144; 3:183; 25:7-8; 51:52; 52:29. Nevertheless, the Hadith, though "almost exclusively doctrinal and ethical in character" (Khalidi 2009, 38), tell stories of Muhammad performing miracles, healing by faith and feeding multitudes through miracles (Khalidi 2009, 46-48). Sira literature also attests to miracles. Of special note are the miracles related to the birth and infancy of Muhammad (Khalidi 2009, 69) and those that take place after Muhammad's prophetic call (79), neither of which, due to their "miraculous elements . . correspond or sit easily with the images of Muhammad in the Qur'an."
} 
The study begins with a discussion of the concept of magic (and miracles) from the perspective of the cognitive science of religion. The cognitive perspective builds on the notion that magical thinking is a universal character of the human mind, as the uncanny similarity of magical representations in various religious traditions suggests. The cognitive perspective is directly linked to the theory of cultural evolution, which describes the transmission and success of various cultural representations. Together, these perspectives address the following questions: how is magical thinking generated in the human brain? Why are magical beliefs universal? Which features make stories of miracles and magic popular and make some more popular than others? Finally, the theoretical discussion is applied to select examples from early Christian literary material relating to the figure of Paul. This treatment enables an assessment of the role of miracle stories and magical enrichment in terms of the cultural success of Pauline Christianity.

\section{Magic, miracle, and cultural evolution}

What is magic? Historically, attempts to understand and define magic have been problematic. Until recent decades, scholarship has tended to follow ancient ethnocentric biases. Scholars of religion, such as E. B. Tylor (1832-1917) and James G. Frazer (1854-1941)_as well as many following in their footsteps-considered magic and religion to be separate categories, the former representing a more primitive stage in human culture than the latter. ${ }^{4}$ Claude Lévi-Strauss noted that the term "magic" was thus applied to derogate groups other than one's own, which was in turn identified as the more sophisticated "religion." 5 In the ancient world, however, the use of the term "religion" was not always clear cut. Persians, who were strongly identified with magical practices by the Greeks, were both despised and imitated for this quality. In the Acts of the Apostles (8:9), Simon Magus is depicted as an adversary, while the three Magi in the Gospel of Matthew are admired for their astronomical wisdom. ${ }^{6}$ Furthermore, the notion that "religion" described a separate sphere of life is quite late, which means that the magic-religion dichotomy suggested by Frazer cannot have existed in antiquity. ${ }^{7}$ In fact, the competition and conflict between various groups seems to have been more about "which approach to magic ... people thought more powerful." 8

\footnotetext{
${ }^{4}$ Czachesz 2007, 2. See also Braarvig, 1999. Primitive cultures were, for example, thought to treat their superhuman agents in a coercive manner, while religions like Christianity and Judaism were thought to consider miracles as being initiated freely by God (Czachesz 2019, 187).

${ }^{5}$ Lévi-Strauss 1962, 220-222. See also Bremmer 2002b, 271. Sørensen 2013, 231.

${ }^{6}$ Czachesz 2007, 4.

${ }^{7}$ Bremmer 2002b, 268; Czachesz 2011a, 145-146.

${ }^{8}$ Czachesz 2011a, 145.
} 
Recent research has again given legitimacy to the term "magic" on new etic and analytical grounds. ${ }^{9}$ According to Jesper Sørensen, ritual acts performed with the conviction that they have actual effect are worth investigating under this common term, suggesting that this could be accomplished by studying the distinct human cognitive mechanisms at work behind magic. ${ }^{10}$ Sørensen himself explains magic mainly through the notions of conceptual integration and ritual. Conceptual integration is the tendency for humans to make inferences between various domains, whether metaphorically ("the king is a lion") or metonymically (i.e., by representing a whole by means of a part). Magic, then, happens when this blending takes place in a ritual, rather than an ordinary, setting. ${ }^{11}$ For Sørensen, conceptual integration further describes the link between the ritual action and the source of efficacy, the powerful or sacred "magical agency." 12

István Czachesz has also called for an understanding of magic from a cognitive perspective. His approach is similar to Sørensen's, though Czachesz criticizes the strict role of superhuman agency in Sørensen's definition. According to Czachesz, magic need not always appeal to superhuman agency, as, for example, various ancient spells attest. ${ }^{13}$ Czachesz offers a three-point definition of magic. First, like Sørensen, he sees ritual efficacy ${ }^{14}$ as the central factor in magic. Magic is meant to produce a real effect, not only to reflect social or psychological realities. In Czachesz's view, magic is not, however, always ritualistic, nor does efficacious ritual always include magic. Secondly, Czachesz insists that magic includes some form of (naïve) theorizing about the reasons behind its effectiveness. Thirdly, Czachesz constrains magical efficacy to the empirical world by insisting that magic should be falsifiable by modern science. This excludes acts that are actually effective (for reasons other than those suggested by the magical explanation) as well as magic that aims to producing effects, for instance, on a merely transcendental or celestial plain. ${ }^{15}$ This last caveat has been the cause for some confusion, since magic, as Czachesz himself admits, often operates on both levels. Exorcism, for example, aims at removing a harmful (supernatural) spirit, which, in turn, has a positive effect on the (natural) person. ${ }^{16}$ Overall, Czachesz's definition is decidedly etic and aims at describing the

\footnotetext{
${ }^{9}$ Bremmer 2002b, 267-278.

${ }^{10}$ Sørensen 2013, 232.

${ }^{11}$ Sørensen 2007; 2013, 233-234.

${ }^{12}$ Sørensen 2013, 233.

${ }^{13}$ Czachesz 2011a, 146. Here, Czachesz criticizes Sørensen's theory as it stood in 2007. Later, Sørensen (2013) seems to have broadened his definition of "magical agency."

${ }^{14}$ On the concept of ritual efficacy, see Sax 2010. According to Sax (2010, 5-6), the idea of ritual efficacy is opposed to the post-Reformation interpretation of ritual as merely representing or symbolizing an underlying reality of, e.g., emotions or religious ideas. When the role of efficacy is accounted for, ritual can be understood as instrumental action (to borrow Talcott Parsons's phrase).

${ }^{15}$ See Czachesz 2011a, 146-148 and Czachesz 2019, 189.

${ }^{16}$ Czachesz 2011a, 147.
} 
cognitive mechanisms behind magical beliefs while leaving open the possibility for different explanations, both magical and non-magical, of the same act. ${ }^{17}$

As for the cognitive mechanisms at work behind magic, Czachesz recognizes three in particular: superstitious conditioning, intuitions about agency and contagion, and interactions with miracle stories. Czachesz has explained all three of these in depth elsewhere (2011) so only a brief summary will be given here. Superstitious conditioning denotes the tendency for humans to overestimate causality, interpreting actions and results as cause and effect, even when no such relationship exists in reality. ${ }^{18}$ Intuitions about agency denote a hypersensitivity to intentional agents in one's surroundings. This trait is a product of evolutionary development and has also been understood as explaining the tendency to imagine the presence of spirits, gods, and demons. ${ }^{19}$ In addition to these, Czachesz believes that magic is also governed by the cognitive mechanism of contagion and contagion avoidance. Several empirical experiments have indicated that humans tend to believe subconsciously in the contagiousness of good and bad features (even abstract moral ones), even in cases where, empirically, such a contagion cannot possibly exist. ${ }^{20}$ As for theories about why and how magical operations work, Czachesz believes that confirmation bias plays significant role. According to this mechanism, humans tend to disregard evidence that might disprove their beliefs while favoring evidence that confirms their existing beliefs. ${ }^{21}$

What then is the relationship between magic and miracles? Czachesz also makes note of the "dynamic interaction" between magic and miracle stories and claims that miracle stories play an essential role in generating and maintaining belief in magic. ${ }^{22}$ It is worth considering here the difference between magic and miracle. First, miracle seems to be used in a much wider sense and normally includes magic. According to the Merriam Webster Dictionary, a miracle is "an extraordinary event manifesting divine intervention in human affairs." The example offered under this definition is "the healing miracles described in the Gospels," which, in Sørensen's and Czachesz's definitions count as magic. Similarly, the Oxford Dictionary speaks of "an extraordinary and welcome event that is not explicable by natural or scientific laws and is therefore attributed to a divine agency." A more mundane definition is also given in the Merriam Webster Dictionary: "an extremely outstanding or unusual event, thing, or accomplishment" (Oxford Dictionary: "an exceptional product or

\footnotetext{
${ }^{17}$ Czachesz 2019.

${ }^{18}$ Czachesz 2011a, 148-149; 2014, 167.

${ }^{19}$ Czachesz 2014, 168.

${ }^{20}$ Czachesz 2014, 169. Czachesz notes that the mechanisms behind contagion and the transfer of qualities between domains (cf. Sørensen's theory) are effectively the same.

${ }^{21}$ Czachesz 2011a, 158; 2014, 171.

${ }^{22}$ Czachesz 2011a, 151; 2014, 171.
} 
achievement, or an outstanding example of something"). Here, the element of counterintuitivity is reduced to normal but exaggerated. Second, a historical ethnocentric baggage often accompanies the use of the term miracle: similar activities may be deemed as miracles in the context of the ingroup but as magic in that of an outgroup. This usage reflects the conviction that the magic-practicing outgroup attempts to (or must) coerce gods and spirits to do their will, whereas the god(s) already show favor to the ingroup and thus perform miracles willingly. ${ }^{23}$ That is, differences in identity rather than ontology have fostered this artificial division.

Czachesz's definition of magic involves some human action (with efficacy), while the term "miracle" is reserved for the literary genre of miracle stories. Thus, Czachesz does not explicitly treat the category of events that are perceived to be miraculous and occurring without human initiative. Czachesz has semi-formally suggested an explanation of the difference between magic and miracle through an analogy of magic and divination. In divination, signs are sometimes generated by human action (e.g., casting lots), whereas at other times spontaneously occurring signs are noted by observation then interpreted. Anders Lisdorf differentiates between these two acts, respectively, as "impetrative" and "oblative" divination. ${ }^{24}$ Czachesz has suggested that we should speak of the category of "oblative magic"- that is, magic offered by a superhuman helper spontaneously, rather than one initiated by a human actor. ${ }^{25}$ Upon closer scrutiny, however, Czachesz notes that there are few such acts. Usually, magical events occur only as a response to prayer, ritual, or the expression of need in some other way. ${ }^{26}$ Another, perhaps simpler, way to describe the role of human and supernatural agents is to understand their activity as a continuum. At one end are, e.g., the spells which do not address divine agents at all (assigning foremost agency to human performers) and, at the other end, are "miracles" performed spontaneously by supernatural beings. Most magical acts fall somewhere in between, and, for some reason, Christian tradition has tended to idealize a minimal role played by humans. All actions nonetheless spring from similar cognitive mechanisms and beliefs and thus belong to a single category.

\footnotetext{
${ }^{23}$ Frazer (1920, 220-243), a proponent of the traditional view of magic, claimed that one of the main differences between religion and magic was that the former "conciliates and propitiates" gods, while the latter "constrains and coerces" them. Czachesz $(2019,187)$ has shown that this distinction is purely imaginary: for example, both the magical papyri and the Christian gospels reveal coercive tendencies along with petitionary ones. In fact, both reflect a complex relationship between the magician and his/her parhedros.

${ }^{24}$ Lisdorf, 2007.

${ }^{25}$ This suggestion by Czachesz has not been published. I refer here to an email-discussion with him and his comments to my paper on magic and miracles in the international SBL meeting in Helsinki, 2018.

${ }^{26}$ In other cases, the unexpected event is interpreted as a sign, thus belonging to the category of divination. Of course, some event can be understood both as magic and divination.
} 
As a literary phenomenon, miracle stories are imbued with qualities that make them attractive and memorable, such as counterintuitive elements, emotionally laden material, and agentive traits. Counterintuitivity denotes features that transcend the natural ontological categories that humans develop through cognitive maturation (e.g., human, animal, plant, artefact, natural object). ${ }^{27}$ Boundaries are crossed, for example, in the concept of a talking donkey or a hearing stone. Studies have shown that stories where ontological categories are crossed minimally, instead of maximally or not at all, are the most memorable. ${ }^{28}$ Pascal Boyer has coined the term "minimal counterintuitivity" to describe this phenomenon. ${ }^{29}$ Counterintuitive elements are to be distinguished from merely exaggerated, bizarre features that do not cross boundaries of ontological categories (such as the gospel stories about catching unusual quantities of fish). ${ }^{30}$ It has also been shown that both strange and counterintuitive elements are more easily remembered when they contain an aspect of agency. ${ }^{31}$ Emotionally arousing elements also enhance memorability of not only emotionally laden details but also other less emotionally laden content in the surrounding material. ${ }^{32}$

What does cultural evolution have to do with magic? The aspects of memorability and the transmission of tradition are directly related to the theory of cultural evolution. While Darwinian evolution can be defined as "variation with inheritance" or as "a process that results in heritable changes in a population spread over may generations," ${ }^{33}$ cultural evolution denotes the variation, transmission, adaptation, and competition between cultural representations, which leads to increases or decreases in the number of cultural variants in a given population. In theoretical discussions, cultural evolution has been considered as analogous to biological evolution. The analogy is not, however, complete. According to Alex Mesoudi, only the macroevolutionary principles of variation, selection, and inheritance fit cultural evolution, whereas the microevolutionary neo-darwinian notions do not. ${ }^{34}$ However, this is not a serious problem to the scientific credibility of cultural evolutionary

\footnotetext{
${ }^{27}$ Keil 1989, 214.

${ }^{28}$ Boyer \& Ramble 2001. Czachesz 2014a, 58; 2014b, 171-172. An increase in counterintuitive elements does not automatically translate to an increase in memorability. On the contrary, too many such elements decrease memorability. For example, folk tales containing too much strangeness have been proven unsuccessful compared to stories with only 0 6 counterintuitive elements (Czachesz 2014a, 59). General context also influences what is experienced as counterintuitive. In the context of a science fiction novel or a religious story, counterintuitive elements are more "normal" and expected and thus add less to the memorability of a story (Luomanen 2014, 32).

${ }^{29}$ Boyer 2002b: 84-87.

${ }^{30}$ Czachesz 2014a, 60.

${ }^{31}$ Steenstra 2005.

${ }^{32}$ Czachesz 2014a, 61.

33 Moran 2006.

${ }^{34}$ The major differences between genetic inheritance and cultural transmission on the microevolutionary level are the following: whereas learned content is not inherited through genes, culture is inherited in a Lamarckian fashion. While genetic variation is produced blindly, cultural variation is often created purposefully. Furthermore, whereas genes are inherited in a particulate all-or-nothing fashion, culture is often blended (and does not consist of particulate faithfully transmitted "memes" in the way suggested by Dawkins) (Mesoudi 2011, 27-54; Czachesz 2017, 25).
} 
theories-especially since cultural evolution can be studied through empirically supported principles also on the microevolutionary level (e.g., concerning transmission). ${ }^{35}$ The theory is based on empirical evidence and quantitative methods, which help to "uncover patterns and trends in cultural macroevolution with greater certainty than is possible with traditional, nonevolutionary methods." 36 Statistical data, mathematical models, and computer simulations have a clear advantage compared to traditional historical and intuitive approaches. ${ }^{37}$

Theories about cultural evolution have not taken a single unified approach but rather a range of different approaches. One major distinction between the different views has to do with the role of biology in cultural evolution. The strictly memetics views of Dawkins, Dennet, and Blackmore give less credence to the cognitive features of the human mind, treating memes as more or less autonomous replicators and, indeed, as the actual driving force behind cultural evolution. Such memes are understood to reside in the human mind and to compete with other replicators for space and survival without any concern for the "vehicle" (= the human mind) ${ }^{38}$ On the other end of the spectrum lie those supporters of nativist evolutionary psychology who stress the role of the human mind in transmitting information. According to these views, the human mind consists of modular (separate) mechanisms that govern behavior; thus, cultural information does not play a significant role in determining what information is transmitted. ${ }^{39}$ In between these two perspectives, realistic views stress the coexistence and joint effect of genes and culture in the transmission of information. Views like these include, for example, Dan Sperber's investigations of culture as an "epidemiology of representations" ${ }^{40}$ and, most notably, the work of Peter J. Richerson and Robert Boyd, which accounts for the role of human psychology plays in shaping and transmitting cultural bits of information.

Richerson and Boyd have, for example, described the manners in which cultural variation is generated, ${ }^{41}$ the various pathways of transmission for cultural information, ${ }^{42}$ and the factors that govern the selection of a cultural trait. Cultural selection denotes the process by which one cultural trait is acquired then transmitted, while another is not. Richerson and Boyd have investigated and

\footnotetext{
${ }^{35}$ For example, Cavalli-Sforza and Feldman (1981) have aspired to formalize the theory of Darwinian cultural evolution by modeling, for instance, the effects of various cultural transmission pathways to cultural evolution. Of equal importance is Boyd and Richerson 1985.

${ }^{36}$ Mesoudi 2011, 83.

${ }^{37}$ Mesoudi 2011, 56.

38 Ylikoski \& Kokkonen 2009, 280-285; Czachesz 2017, 26.

${ }^{39}$ Mesoudi $(2011,12)$ gives the theory of "evoked culture" by Leda Cosmides and John Tooby as an example of this line of thinking. According to this view, people essentially have a similar inherent repertoire of behaviors, which can be differently triggered by environmental factors. See e.g. Cosmides \& Tooby 1994.

${ }^{40}$ Sperber 1996, 2000.

${ }^{41}$ Such as random innovations and purposeful generation-i.e., Lamarckian inheritance, called "guided variation" by Richerson \& Boyd (see the summary in Mesoudi 2011, 63-64).

${ }^{42}$ Such as vertical, oblique, and horizontal transmission (see the summary in Mesoudi 2011, 58-61).
} 
classified various factors that make cultural bits attractive and contribute to their selection and success in the population. These factors (called "content biases") include such traits as-and here is the link to magic and miracle stories-counterintuitivity and emotionally laden content. There are also factors for the selection of cultural traits that have less to do with the attractiveness of the cultural bit itself as with external factors, such as frequency (copying the most popular trait) and model biases (copying traits favored by prestigious people or people similar to oneself). ${ }^{43}$

Until recently, biblical scholarship has made little use of cultural evolutionary theories, though evolutionary and social scientific studies concerning the success of religion or, more specifically, Christianity have been conducted. ${ }^{44}$ Among the first attempts is Petri Luomanen's article (2013), which discussed the disappearance (unsuccessfulness) of Sayings Gospel Q in comparison to the successful reproduction and spread of the gospels of Mark and Matthew. Luomanen articulates a fourpronged model for detecting features in the texts that could explain their respective success. The first category has to do with formal characteristics of the discourse. This aspect is closely related to what Richerson and Boyd call "content biases" and includes features such as attractiveness, memorability enhancing features, and credence. The other categories, on the other hand, have mostly to do with group selection. That is, they describe features that contribute to the formation, success, and maintenance of the groups that advance the survival of a text. The second analytical category is directed at network discourse and community control, such as the existence and promotion of norms, the free-rider problem, and the creation of open networks/weak links ${ }^{45}$ to the outside world. The third category applies insights from the social identity approach to identify discourses concerning prototypes, social memories, symbolic identity markers, and the like. The fourth category concerns discourse in the text related to ritual. ${ }^{46}$

This article will deal with Pauline material from the authentic letters of Paul to Acts and early apocryphal material relating to Paul, most notably the Acts of Paul and Thecla. The task is not to discuss the writings as a whole from a cultural evolutionary perspective but to focus on the role these texts plays in adding to the material on magic and miracles surrounding the figure of Paul. My hypothesis is that their role has mostly to do with what Luomanen has deemed "formal

\footnotetext{
${ }^{43}$ See Mesoudi 2011, 64-76.

${ }^{44}$ Stark 1996; Theissen 1984; Wilson 2002.

${ }^{45}$ Here, Luomanen is dependent on Stark's notion of open networks as a necessary medium for the spread of early Christianity (Stark 1996, 73-94; Luomanen 2013, 51). See also Czachesz 2011b and his updated considerations in 2017, 202-3. Czachesz further argues that "there were more weak links in Early Christianity than in other religious groups" $(2011 \mathrm{~b}, 142)$ due to the central role of women and itinerants as well as the practice of charity towards outsiders. Importantly, Czachesz also argues that the multitude of weak links contributed to the production and innovation of cognitively optimal ideas (2011b, 153).

46 Luomanen 2013, 55.
} 
characteristics." This means that their major contribution to the spread of Pauline Christianity has likely been that they have stuck to people's minds as fascinating stories. The other categories of Luomanen's model—particularly identity maintenance, community control, networks, and ritual— are perhaps more prominent in other parts of the literature and are thus worth keeping in mind.

Furthermore, the following examples of magic in canonical and apocryphal Pauline material are explored through Czachesz's category of magic, though not dogmatically. It is important here to note that what enhances learning and memorability in these texts transcends the boundaries of modern etic definitions of magic. As Czachesz himself admits, miracle stories were and are successful regardless of their magical elements, inasmuch as they contain attention-grabbing counterintuitive and remarkable features as well as emotionally laden contents. ${ }^{47}$ The connection between magic and miracle in these texts nevertheless offered readers ways to familiarize themselves with magical concepts, thereby demonstrating "a repertoire of magical manipulations." 48

The introduction of magical concepts through such texts is closely related to the phenomenon of magical enrichment, by which Outi Pohjanheimo refers to "an observable thickness (or density) of spontaneous reasoning going along lines of magical trains of thought," which includes "for example, assumptions of agency and magical contagion."49 Pohjanheimo (2014) has studied how magical thinking is encouraged and stimulated in modern Reiki-healing communities, but a somewhat similar process was probably taking place in early Christianity as well. That is, as Czachesz suggests, miracle stories fostered magical thinking in the audience but also, and more interestingly from the perspective of cultural evolution, strengthened the familiarity of magical thinking to narratives surrounding Paul.

\section{Magic and miracles in Paul's letters}

First Thessalonians, the earliest textual evidence of what was to become Christianity, is scarce in references to magic. The beginning of the letter recalls Paul's initial visit to Thessalonica. The conversion of the Thessalonians (or election, $\dot{\eta} \dot{\varepsilon} \kappa \lambda \circ \gamma \eta$ ) is described as receiving the gospel not only in words but "in power" and "in the holy spirit" (

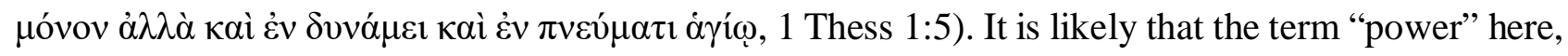
as elsewhere (1 Cor 12:10, 28), denotes some form of miraculous activity. The activity is closely linked to the holy spirit, which means that the reception of the gospel is also linked to the reception

\footnotetext{
${ }^{47}$ Czachesz 2014, 172.

${ }^{48}$ Czachesz 2014, 173-174

${ }^{49}$ Pohjanheimo 2014, 294.
} 
of the holy spirit. Czachesz has argued that the holy spirit in early Christianity is comparable to the parhedros of the Greek Magical Papyri. In these magical texts, the parhedros ("one who sits nearby/near") is the magician's supernatural assistant, who appears either in human form or as a divinity or a demon, sometimes even as a physical object. ${ }^{50}$ According to Czachesz, many instances of early Christian magic are in line with the actions of parhedroi in magical papyri (e.g., delivery from prison, exorcisms, killing enemies, and magical manipulations of wine and food). ${ }^{51}$ According to this analogy, Paul's description of the reception of the gospel and the holy spirit could be understood as the initiatory process required to receive such a parhedros. ${ }^{52}$ It is important, however, to note that the Greco-Roman magical tradition was not the only context that could have influenced stories around Paul; that is, it is more realistic to refer to a supernatural agent in a wider sense. Moreover, Paul never distinguishes clearly between the holy spirit and the risen Christ, the latter of whom notably can also be known in spirit form. ${ }^{53}$ This means that both agents can, and do, appear as parhedroi, or supernatural agents. Lastly, the conversion event is significant in its divine legitimation of Thessalonians' identity as believers through special contact with the holy spirit.

The bulk of 1 Thessalonians is otherwise void of magical reference, particularly in relation to everyday life. In fact, the recurring mentions of toil and exhortations to work with one's own hands $(2: 9 ; 4: 11)$ seem to emphasize the ordinariness of life. Miraculous events are, however, described in the apocalyptic section of the letter, which vividly describes the coming of Christ, the resurrection of dead bodies, and the reunion of all in heaven (4:13-18). All these events can, more or less directly, be understood as the work of the parhedros. These depictions of oblative magic are filled with counterintuitive and extraordinary features, which enhance their memorability. Its events are also potentially falsifiable - that is, they are not depicted as symbolic but real events. However, the burden of verification is pushed far into the future. In terms of general magical thinking in Pauline communities, it is significant that these imagined magical or miraculous happenings are placed at the very core of the religious narrative. This both reflects and further fosters magical thinking in the audience.

Another example can be found in 1 Corinthians 12, where Paul speaks briefly about religious

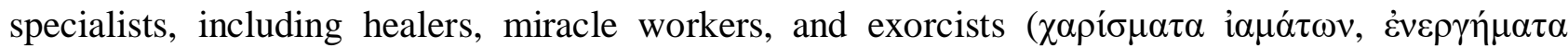

\footnotetext{
${ }^{50}$ Scibilia 2002, 75-76; Czachesz 2011a, 157. Christian literature ascribes parhedroi to outsiders-e.g., Irenaeus (Haer. 1.13.3) describes the heretic Marcus Magus as possessing a demonic parhedros. See Bremmer 2002, 54.

${ }^{51}$ Czachesz 2011a, 157.

${ }^{52}$ Admittedly, no complicated ritual is described; on the various rites behind the acquisition of a parhedros in the PGM, see Scibilia 2002.

${ }^{53}$ Kuula 2003, 49-54.
} 
$\delta v v \alpha ́ \mu \varepsilon \omega v, \delta 1 \alpha \kappa \rho i ́ \sigma \varepsilon ı \varsigma$ $\pi v \varepsilon v \mu \alpha ́ \tau \omega v) .{ }^{54}$ These magical specialists are mentioned together with others whose religious specialty, though emphatically claimed to derive from the same spirit (1 Cor 12:46), does not include counterintuitive or supernatural elements. Some of these are unequivocally nonmagical (12:28-29: teachers, helpers, leaders), while others are more ambiguous (words of wisdom or knowledge, prophecy, or glossolalia or the interpretation thereof). If glossolalia were to be understood as spontaneous knowledge of a foreign but real language, in the manner of the Pentecost story of Acts (2:1-13), the supernatural type of learning would be falsifiable and thus fit Czachesz's definition. Paul's references to unintelligible speech in 1 Cor 14:2, however, make it unlikely that this is meant. Similarly, prophecy can be falsifiable, if it is understood as foretelling the future, but the non-supernatural functions Paul gives it fall outside the realm of falsifiability ("building up and encouragement and consolation," 1 Cor 14:3). ${ }^{55}$

It is noteworthy that the authentic letters of Paul represent the oldest surviving evidence of magic in early Christianity. The gospel stories of Jesus performing miracles are considerably later. In fact, the miracle-making Paul of Acts is the actual contemporary of the Jesus of the gospels. This circumstance brings Czachesz to ask if, in fact, early Christians undertook magic, "because they heard such stories about Jesus and the apostles, or did they tell stories like that because they were practicing magic?"56 Czachesz further suggests that Christianity may have "incorporated already existing magical lore" and that "magical specialists who converted to Christianity could be among the healers and miracle workers mentioned in 1 Corinthians." 57

Interestingly, while clearly admitting and condoning the use of magic among the Corinthian believers, Paul explicitly stresses the primacy of an ordinary quality: love (1 Cor 13). A similar emphasis is found in 2 Corinthians, where Paul—while admitting his capacity to perform "signs and wonders and

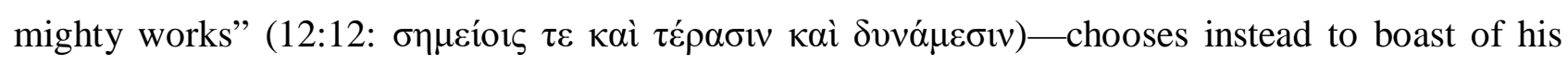
physical toils and weakness (11:16-30).

In sum, Paul's authentic letters do reveal a clear presence of magical beliefs and practices in his churches. In his speech, however, Paul tends to diminish its role, stressing the primacy of ordinary life and ethics. Here, Paul may represent the sort of caution towards "magic" that helped to establish him as a traditional (Jewish) religious leader. ${ }^{58}$

\footnotetext{
${ }^{54}$ Czachesz 2011a, 155-156.

55 On the magical aspects of the Eucharist as described in 1 Cor, see Vojtěch Kaše's article in this book.

${ }^{56}$ Czachesz 2007, 314.

57 Czachesz 2011a, 156.

${ }^{58}$ See, e.g., Nils Hallvard Korsvoll's article in this volume on the aversion of "official" religion to amulets which, despite such "unison disapproval," remained immensely popular among non-elite believers.
} 


\section{Magic in narratives and epistles of Pauline heritage}

From Paul's authentic letters onwards, Pauline tradition takes two different directions regarding magic and miracles. As was noted above, Paul's letters point in either direction. Supernatural happenings abound in the narratives of the Apocryphal Acts. In the deutero-Pauline letters, on the other hand, they are scarce. ${ }^{59}$ As we will see below in the brief analysis of Colossians, this does not mean that magical (or related) beliefs are completely absent. The worldview of the letters is still supernatural: in Ephesians, Paul is the recipient and guardian of a heavenly mystery (3:3), and the church is said to be protected from evil powers in its role as the body of Christ $(1: 19-22) ; 2$ Thessalonians is rich with apocalyptic imagery and even refers to miracles performed by the Antichrist, perhaps in critique of magical practices by contemporaries. Nevertheless, theological complexity and conservative ethics seem to have supplanted the attention-grabbing miracle stories that were ascribed to the person of Paul.

One way of comparing the narratives about and letters of Paul, besides their orientation to magic and miracles, is how Paul imitates Christ. In the letters, Paul is styled as suffering like Christ, while the narratives emphasize miracle-making as the chief form of imitation. ${ }^{60}$

Colossians, the oldest deutero-Pauline letter, already demonstrates well, which general direction this strand of the Pauline heritage was to take. ${ }^{61}$ There is clearly little interest in magical happenings or narrative. This is a natural consequence of the literary genre but also reveals a genuinely different treatment of tradition. What little is told of Paul's historical character is made up for by a focus on the details of his mundane sufferings, which, interestingly, also gain a soteriological significance ("for you," 1:24). In some sense, Paul is on his way to becoming a supernatural being himself. ${ }^{62}$ The role of the spirit, on the other hand, is diminished: ethical actions are empowered by baptismal resurrection (2:6-15) and governed not by the spirit but by fixed rules. ${ }^{63}$ Furthermore, the letter continuously shows explicit interest in community formation and discipline-for example, in the form of the Household Codes. Glossolalia is not mentioned at church meetings (3:16), and, in Ephesians, the list of religious specialists no longer includes miracle workers (4:11). Thus, while

\footnotetext{
${ }^{59}$ For an overview of the various trends that can be discerned from the deutero-Pauline letters, see Pervo $2010,63-118$.

${ }^{60}$ Pervo 2010, 150.

${ }^{61}$ To be sure, pseudepigraphical, Pauline letters are by no means a unified category. The letters do not agree on major topics, nor are they related to each other. Consider, for instance, the difference between the realized eschatology of Col and Eph to the apocalypticism of 2 Thess.

62 "Paul is becoming a redeemer figure." Similarly, Ephesians includes "a meditation on Paul's place in salvation history" (Pervo 2010, 70, 74).

${ }^{63}$ Pervo 2010, 67-68.
} 
narrative Pauline material is rich in formal memorability-enhancing qualities, the deutero-Pauline letters seem to be more concerned with group identity formation (cf. Luomanen's model for cultural evolutionary factors).

Additionally, Colossians testifies to an increasing complexity in Early Christian theology. The tendency is especially visible in the highly abstract depiction of Christ as the head of the church and as the dwelling place of "all the fullness of God" (Col 1:18-19). In connection with the obscurity of such language, Daniel Ullucci, who has researched the role of religious ideas incompatible with human cognitive hardware due to their massive complexity and overstated counterintuitivity, suggests that, unlike their cognitively optimal counterparts, such complex and cognitively taxing ideas require a great deal of time, effort, and analysis by religious experts to survive. This cognitive demand guarantees the importance of the idea while making the religious expert invaluable to his or her community. ${ }^{64}$ It is worth noting, then, that these complex and norm-centred letters would later be incorporated to the canon instead of the apocryphal Acts, the latter of which enjoyed a more popular readership (see below).

\section{Magic and miracles in the Canonical Acts}

Compared to Paul's letters, magic takes on a much more significant role in the canonical Acts' story of Paul (and the other apostles). ${ }^{65}$ Likewise, miracles and magic are essential to the depiction of Jesus in the gospels. This unwitting similarity between the Acts and the gospels can be explained by the fact that the Jesus of the gospels is a contemporary of the Paul of Acts (and apocryphal Pauline material) rather than a faithful report of the historical Jesus. This is not to say that Jesus was not historically a healer and miracle worker, as mainstream research suggests—only that this theme was likely to have become more common and central over time. There are several possible explanations for this general development. First, the discrepancy has to do with literary genre: gospels, Acts, and apocryphal Acts tend to follow the style of Hellenistic novel in their focus on miracle-making. ${ }^{66}$

\footnotetext{
${ }^{64}$ Ullucci 2014, 26.

${ }^{65}$ A similar example can be found in the figure of Apollonius of Tyana, whose letters reveal little magical or miraculous but who becomes, under Philostratus's pen, a paragon of ancient miracle workers (Koskenniemi 1998, 460).

${ }^{66}$ This is, of course, an oversimplification, as the ancient Greek novel (or romance) is itself an ambiguous category (Thomas 2003, 3). Nevertheless, ancient Greek novels and apocryphal Acts have commonly feature, for example, an interest in travel, aretology, wonders, propaganda, and eroticism (for a criticism of the comparison of these genres by Rosa Söder in 1932, see Thomas 2003). Thomas (2003), admits that "the genre most closely comparable to these works is the ancient novel" but notices that the "serious historical intent" of the apocrypha "separates them from the later, more self-consciously fictive novels, and maintains them within the realm of the earlier historical novels produced by ethnic subcultures within the Roman empire." While the apocryphal Acts are most often associated with ancient romance, the canonical Acts are generally compared to ancient historiography (Thomas 2003, 6). The latter is no unambiguous match
} 
Another (related) factor is that of magical enrichment: miracle stories address the human cognitive faculties, entice them, and tend to foster magical thinking.

Acts 2 and 19 relate the ritualized reception of the spirit. The first instance is the so-called Pentecost story, where Paul is not yet a member of the group of Christ-followers. The ritual context of the event is only hinted at, but their having congregated in one place strongly suggests that some form of prayer had also taken place. The reception of the spirit then brings about the magical ability to speak a foreign language previously unknown to the speaker. A similar situation is described through baptism and Paul's ritualistic laying on of hands in Acts 19, where disciples of John the Baptist receive the spirit and immediately begin to prophecy and speak in tongues. Similar initiatory rituals are also described in Acts 8:15-16 (through laying on hands); 10:44 (during Peter's speech).

In addition, the stories of the apostles' supernatural breaks from prison form a set of remarkable examples of magic. The one depicted in Acts 5:19 is terse: the imprisoned apostles (excluding Paul at this point) are simply released by a visiting angel; no human initiation or ritual is depicted, though one can be inferred. In Acts 12, Peter alone escapes with the help of an angel in a story rich in detail. In Acts 16, Paul and Silas escape from prison in Philippi by "praying and singing hymns to God," which causes an earthquake that shakes the prison. These acts constitute a ritualized action and a simple "theory" that explains the magical effect.

Such stories of supernatural release from prison find interesting analogies in both magical spells and Hellenistic novels. A Greek Magical Papyrus (PGM 1:96-130) mentions opening doors and freeing one's chained as something that can be accomplished with the help of a parhedros. A Coptic Christian spell, where Mary is clearly invoked as the supernatural helper, refers to the same phenomenon: "Let the rock [split], let the darkness split before me, [let] the earth split, let the iron dissolve <...> (London Oriental Manuscript 6796[2], 9-25, trans. Meyer 2002) ${ }^{67}$ Finally, Philostratus's depiction of the miraculous escape of Apollonius is an interesting comparandum from the genre of Hellenistic novels (Life of Apollonius 7.36-40). ${ }^{68}$

Acts is, furthermore, abundant in healing stories, featuring Paul prominently in 14:8-10; 19:12; $28: 8-$ 9. In one story, Paul also raises a boy from the dead (20:9-10) and, in another, proves to be immune

either (Thomas 2003, 3), and Thomas in fact strongly questions the artificial distinction between the canonical and apocryphal Acts (2003, 7-10).

${ }^{67}$ Meyer 2002, 407-415.

68 The role of Apollonius himself as an agent and supernatural figure is heightened by the absence of any other divine helper: "Damis says that it was then for the first time that he really and truly understood the nature of Apollonius, to wit that it was divine and superhuman, for without sacrifice—and how in prison could he have offered any? - and without a single prayer, without even a word, he quietly laughed at the fetters, and then inserted his leg in them afresh, and behaved like a prisoner once more" (7.38). 
to snake venom (28:3-6). Another interesting genre of magical stories is that of magical competition, with Paul depicted as main character in Acts 13:6-12; 19:11-20. The Apostle Philip, on the other hand, competes with Simon Magus in Acts 8. ${ }^{69}$ In Acts 13, Paul meets a Jewish magician ( $\mu$ óyos), Bar-Jesus (= Elymas), in Paphos. Elymas tries to dissuade the proconsul from listening to and believing in Paul's message; in response, Paul strikes Bar-Jesus blind with an act of magic. As Czachesz has noted, Paul's criticism in the passage is not directed at Elymas's magical behavior per se, even though he is described as an evil magician, but rather at his attempt to obstruct the transmission of the gospel. Furthermore, Paul is said to have acted while "filled with the holy spirit," a description that highlights the importance of having the correct supernatural helper. ${ }^{70}$ In the story of Paul's stay in Ephesus (Acts 19), on the other hand, a magical competition takes place between Paul and the sons of the high priest Sceva. The Ephesus story depicts various magical and miraculous happenings around Paul ("when the handkerchiefs or aprons that had touched his skin were brought to the sick, their diseases left them, and the evil spirits came out of them"), but when the sons of Sceva attempt to perform an exorcism in Jesus's name, the evil spirit attacks them. Here, again, the point of the story is not to distinguish between magic and religion, but that, "as in the other two conflicts with magicians in the Book of Acts, magic is confronted with magic."71 This means that the main question has to do with the magician's relationship with his or her divinity.

The stories of magical competition are certainly memorable, but they are also significant in terms of identity discourse. First, they depict Paul as an ideal prototype for believers, though it is unclear to what extent all believers were expected to be able to perform such magic. ${ }^{72}$ Second, the opposition in these stories of Paul and the other magicians reveals a typical categorization between "us" and "them": the actual practices may be closely similar, but a difference still needs to be made on some symbolic or verbal basis. "They" are magicians; "we" are believers. Third, it is important to have the correct supernatural helper. The specific divine assistant is a clear symbolic identifier that distinguishes one group from others. Interestingly, adopting the mere symbol is not enough (cf. the

\footnotetext{
${ }^{69}$ For a treatment of this episode from the perspective of magical competition, see Czachesz (2011, 144), who stresses that the difference between Philip and Simon in the story is not phenomenological, even though Simon is depicted as a magician and "the other." In later Christian material, Simon Magus competes with Peter (Acts of Peter 23; see Bremmer 2002, 62-66). In the Pseudo-Clementine Recognitions, Simon Magus, who bears the characteristics of Paul and Marcion, is set up as the archenemy of Peter.

${ }^{70}$ Czachesz 2011a, 144.

${ }^{71}$ Czachesz 2011a, 145 (emphases his).

${ }^{72}$ Usually, it is only the heroes who perform magic, but the long ending of Mark (from the first half of the second century) suggests that all believers would perform miraculous deeds ("by using my name they will cast out demons; they will speak in new tongues; they will pick up snakes in their hands, and if they drink any deadly thing, it will not hurt them; they will lay their hands on the sick, and they will recover." 16:17-18). See Czachesz 2011a, 156.
} 
sons of Sceva), as true membership entails certain costly commitment, that in turn limits exploitation by free riders. ${ }^{73}$

\section{Magic and miracles increase: The Apocryphal Acts}

The Apocryphal Acts are a series of five early Christian writings written between the latter half of the second century and the first decades of the third century. The oldest is probably the Acts of John, followed by the Acts of Paul, the Acts of Peter, the Acts of Andrew, and finally the Acts of Thomas. The novels were not composed as a collection, and the writers remain unknown. ${ }^{74}$ In the following evaluation, examples of magic will mainly be taken from the Acts of Paul, ${ }^{75}$ where Paul, in addition to the examples elaborated on below, performs a host of such "standard" magical acts as healing (AP 4), resurrection (AP 4, 8, 11), ${ }^{76}$ and escape from chains (AP 7).

The Acts of Paul and Thecla, which forms a large part of the Apocryphal Acts of Paul, contains a significant number of miracle stories, though Paul himself as a magic maker often gives way to Thecla, who is the actual protagonist. ${ }^{77}$ The novel tells the story of Thecla, a young Iconian woman engaged to a man named Thamyris. Thecla hears Paul's message and decides to follow him, choosing a life of abstinence instead of marriage. ${ }^{78}$ However, local administrators repeatedly endanger Thecla and Paul for following the gospel. Subsequently, when one or the other is in mortal danger, a miracle tends to be performed.

One interesting case of magic is the appearance of "the Lord sitting in the likeness of Paul" in the crowd, as Thecla is about to be burned at the stake (AP 3.21). The mechanism behind this fantastic shape-shifting is not explained, but the story clearly describes transformative magical action, where qualities are transferred from elements of one domain to elements of another (the Lord being

\footnotetext{
${ }^{73}$ For an economic analysis of costly signals as a means of deterring free riders in religious groups, see Iannaccone 1992. ${ }^{74}$ Elliot 1993, 229 (the uncertainty of the order between the Acts of Paul and John is also discussed here). Bremmer 2002, 51.

${ }^{75}$ For a summary of the book, see Klauck 2008, 47-79. The Acts of Paul was originally an extensive work (cf. its 3,600 stichoi to the 2,600 of the canonical Acts), which has not survived in its totality. The novel includes various independently written parts (Acts of Thecla; 3 Corinthians; Martyrdom of Paul), which are woven together with other material into one composition. There are notable similarities in the book to the canonical Acts and the Pastoral epistles (Klauck 2008, 7374). The two most important manuscripts (of the full-length text) are the sixth-century Coptic papyrus from Heidelberg and a Greek papyrus from Hamburg from ca. 300 (Klauck 2008, 47-49).

${ }^{76}$ Bremmer (2002, 67-69) offers several examples of magical resurrections in non-Christian literature-e.g., from Apuleius: Metamorphoses; Philostratus: Apollonius of Tyana; Polemo: De physiognomia; Lucian: Lover of Lies \& Alexander the False Prophet.

77 Klauck 2008, 60.

${ }^{78}$ Indeed, Thecla seems in many ways to be in love with Paul; see, for example, the description of Thecla by Theocleia in AP 3.8 (see Spittler 2008, 162: "a classic case of love sickness") and Thecla's behavior when visiting Paul in prison (AP 3.20). For the ubiquity of love magic in Greco-Roman myth and literature, see Faraone 1999.
} 
transferred to Paul). The same scene recounts Thecla eventually being saved from the pyre by a sudden rainfall (3.22). To heighten the suspense, the reason for the rain is only given later, when it is revealed that Paul and the family of a certain Onesiphorus had been fasting and praying for Thecla for six days (3.23). The story is a classic case of magical rainmaking, amply attested in other contemporaneous sources. ${ }^{79}$

Interestingly, the apocryphal Acts of Paul elsewhere, too, emphasizes ritualized fasting as a means of achieving magical efficacy (e.g., AP 8). This reveals the impetrative nature of the magical action and further highlights certain identity-forming aspects. Recurrent mentions of fasting suggest to the reader that Christian identity and the ability to apply Christian magic is a costly endeavor. A similar message of costliness is communicated by the many references to abstinence (e.g., AP 3.5-6) and, of course, by constantly placing the prototypical heroes into situations, where they must choose faith over their own lives. $^{80}$

Interestingly, while staying in the tomb with Onesiphorus's family, Paul is unable to produce food for the company via magic and must send a child to sell his cloak to be able to afford bread. While this is necessary for the storyline so that the child can meet Thecla on the way, it may also highlight beliefs related to magic. When concentrating on rainmaking, Paul may be unable to perform other miracles simultaneously. ${ }^{81}$ Furthermore, the story may wish to emphasize the "seriousness" of Christian magic by the same rationale with which Peter in the Acts of Peter refuses to perform tricks of flight just to impress his Roman audience: that is, magic is permitted chiefly when conventional methods do not work and only when God allows it. ${ }^{82}$

Paul's companion and the main character of the novel, Thecla, also performs miracles. In the case of the latter, just as lions are expected to attack Thecla, they suddenly act in a friendly and protective way towards her $(3.28,3.33)$, in an emotionally arousing and extraordinary scene. ${ }^{83}$ Interestingly, the mere strangeness of the friendly lion is intensified to ontological counterintuitivity in another part of the Acts of Paul, where Paul, also fighting in the arena, meets a friendly lion that actually speaks,

\footnotetext{
${ }^{79}$ For example, Honi the Circle drawer, who was well known for his rainmaking abilities (Josephus, Ant. 14.2.1.22-24). Cassius Dio (Roman History 72.8) tells the story of a miraculous rain during Marcus Aurelius's military campaign.

${ }^{80} \mathrm{Cf}$. Thecla's "two martyrdoms" in 3.20f, 3.32f; see also 7; 11.4, where administrators ask Paul "Whence have you this king that you believe in him without changing your mind even at point of death?".

${ }^{81}$ An instance of theological incorrectness perhaps (see Barrett 1999).

82 Bremmer 2002, 70. A similar emphasis can be discerned in Buddhist tradition. Under monastic rule (Vinaya), the Buddha is said to have forbidden the performance of miracles to laity, once reportedly comparing them to a woman exposing herself for a few coins (Gethin 2011,222).

${ }^{83}$ Spittler $(2008,176)$ also notes that the failure of the first lioness to attack was not "a particularly miraculous event," since the beasts were often scared and wanted to claw their way back into the cage. For a full treatment of the role of animals in the Acts of Paul with recourse to ample parallels in Hellenistic novels, see Spittler 2008, 156-189.
} 
recalling that Paul had earlier baptized him (AP 7). ${ }^{84}$ Here, the audience in the arena also becomes aware that something is amiss and accuses Paul of sorcery. Klauck has shown the influence of the Hellenistic story of Androclus and his lion (Aulus Gellius: Attic Nights 5.14.5-30) on this parallel storyline in the Acts of Paul. The story of the friendship between Paul and the lion, however, exceeds its Roman counterpart in counterintuitivity. This is not in fact completely unexpected, since novel cultural information needs to be distinguished from its context and added upon to ensure its memorability. Interestingly, though, the writer of Paul's arena-incident suddenly seems to become aware of the dangers of excessive counterintuitivity and stresses that, after his discussion with Paul, "the lion went away to the mountains as was natural for it."

In the scene with the wild beasts, Thecla eventually also baptizes herself in a pit of water. ${ }^{85}$ The efficacy of this baptism is emphasized in the story, as she throws herself in the pit "in the name of Jesus" and the seals in the water behold a flash of lightning, are struck dead, and carcasses immediately float to the surface of the water. Further miracles ensue: after this baptism, "a cloud of fire" surrounds Thecla so that the beasts cannot reach her and so that no one can see her naked (AP 3.34).

The narrative of Paul's martyrdom (AP 11) also contains several imposing instances of magic. Among the most interesting is the story of the haunting Paul. Faced with the death penalty, Paul threatens (or simply announces?) ${ }^{86}$ that he will come back and appear to the emperor after his death ("if you have me executed ... I will rise again and appear to you, for I shall not be dead but alive to my king Christ Jesus," AP 11.4). After Paul's miraculous death, when the emperor is having a discussion with some philosophers and the centurion, Paul indeed appears and speaks to the emperor, foretelling the "many evils and great punishment" that will come upon him because of his unjust bloodshed (AP 11.6). Later, Paul also appears to his followers, praying at his own (!) grave (AP 11.7). The counterintuitivity of someone living after having been beheaded is striking, nor is there a shortage of parallels with Christ's appearance stories in the Gospels.

Perhaps the most famous and memorable incident, however, is the moment of Paul's death (AP 11.5): "when the executioner cut off his head milk splashed on the tunic of the soldier." The miracle is extraordinarily counterintuitive, as blood transforms to milk. This transformation also has an undeniably emotional quality, as a disgusting and frightening fluid has been transformed into

\footnotetext{
${ }^{84}$ A Coptic papyrus from the Bodmer collection (P. Bodm. LXI) tells the story of the baptism of the lion soon after Paul's conversion. After being baptized, the lion also becomes abstinent, which is proven during his encounter with a lioness (see Klauck 2008, 64; Spittler 2008, 183).

${ }^{85}$ These pits were used. e.g., for staging sea-battles (Klauck 2008, 58).

${ }^{86}$ Klauck 2008, 71.
} 
something pure, white, and nurturing. ${ }^{87}$ Paul's lengthy prayer precedes the miracle, making it an instance of impetrative rather than oblative magic.

My hypothesis is that the amount of miracle stories increases in the apocryphal Acts as compared to the canonical Acts. ${ }^{88}$ Nevertheless, the sheer number of magical stories is not the key factor. In fact, the magic of the apocryphal Acts is enriched by enhanced counterintuitivity and heightened emotional arousal. There are, for instance, no speaking lions in the canonical Acts, yet the work does avoid the perils of excessive counterintuitivity by also incorporating long sections of ordinary events and reactions. This kind of alternation between intuitive and counterintuitive elements is, in fact, the ideal model for memorability. ${ }^{89}$ The lack of magical references in the section comprising the Third Letter to the Corinthians supports the above hypothesis of a two-tiered development of magical narrative versus non-magical letters.

The richness of magic is also relativized by expectations of similar acts in the surrounding culture and literature. Namely, apocryphal literature builds on earlier literature, such as the canonical Acts, which already contains an array of magic and miracles. Thus, apocryphal literature must respond to the demand to distinguish itself in a memorable way from existing literature, a demand that is quite naturally met by enhancing its magical material.

\section{The popularity of early Christian magical narratives}

The original hypothesis of this paper was that magical/miracle stories increased the popularity of Pauline Christianity in the first centuries. The apocryphal narratives related to Paul did indeed quickly become popular. According to Hans-Josef Klauck, the Acts of Thecla in particular, with its 80 surviving early manuscripts, was "extremely popular." 90 The Martyrdom of Paul, on the other hand, is known from four Greek manuscripts. Both Thecla and the Martyrdom have also survived in several translations. ${ }^{91}$ Furthermore, Tertullian mentions the Acts of Paul in ca. 200 CE (Bapt. 17.5), as well as Eusebius, who judges the work as spurious but not heretical (Hist. eccl. 3.25f). ${ }^{92}$

\footnotetext{
${ }^{87}$ On the effectiveness of disgust on memorability, see Czachesz 2011a, 155.

${ }^{88}$ That the difference is more quantitative than qualitative has implications for the genre of the works. That is, it is not simply a matter of the canonical and apocryphal Acts being different genres-e.g., one being historiography and the other frivolous entertaining romance. See note 64 above for a discussion on genre.

${ }^{89}$ Czachesz 2014a, 59.

${ }^{90}$ Klauck 2008, 49.

${ }^{91}$ See Klauck 2008, 49-50.

${ }^{92}$ Pervo (2014) lists more than 20 instances of knowledge of the AP in early Christian sources, such as Hippolytus's In Danielem 29.3, three references by Origen, references by Commodian and Methodius, mentions in the Didascalia, and the inclusion of the AP in the list of biblical books in codex Claromontanus.
} 
Jan Bremmer views the early Christians' keen interest in magic against the politico-historical backdrop of the time. According to him, the Apocryphal Acts reflect "the short period between the birth of Christianity and the arrival of the Constantine and Christian Empire," when "magic and [Christian] miracle were strong competitors for attention." ${ }^{93}$ Stories of magical competition can be understood as narrative reflections of this rivalry. Bremmer believes that, after the Christianization of the Roman Empire, interest in magic decreased, since Christians were able to eliminate the competition. Bremmer's contextualization does, however, need some corrective and clarification. First, as was pointed out with the examples at the beginning of this article, the enrichment of magical thinking seems to be a universal phenomenon. Influential figures attract magical beliefs and stories regardless of the given political situation. As a result, people tend to become familiarized with magical thinking and associate it with their own tradition and identity. Second, Bremmer's statement about declining interest in magic after Constantine needs further examination. While dogma and determination of norms perhaps gained currency in elite circles, magical beliefs certainly thrived among more common religious adherents. After all, a trajectory of some sort runs from Paul the magician in Acts to Paul the Saint (and "parhedros"), who still receives prayers from modern-day Roman Catholics.

Another important question concerns the role of magical enrichment for Pauline Christianity in particular. This is harder to pinpoint, since it seems that miracles and magic increase similarly in the stories of the other apostles as well. The reasons behind this are probably twofold. First, the development can be understood as cognitively induced magical enrichment based on content biasthat is, a normal tendency for the human mind to find magic interesting and memorable. Second, it may be a matter of prestige bias - that is, of following the example of a prestigious model, in this case, the Jesus of the gospels and/or Hellenistic novels. This means that the increase in magic was also dictated by trends in the surrounding culture.

The distinction between Pauline and other kinds of Christianity is also complicated by the fact that the apostles and the traditions related to them tend to blend together and become more similar over time. The further we move away from the authentic letters of Paul, the harder it becomes to distinguish Paul from other influential early Christian characters. Many have observed, for example, the "switched" roles of James and Paul already in the Acts' depiction of the Jerusalem meeting and the Pauline character of the canonical First Epistle of Peter. ${ }^{94}$ Thus, whereas the narratives around the

\footnotetext{
${ }^{93}$ Bremmer 2002, 70. Note the difference between Bremmer's distinction between magic and miracle and the definition proposed in this article.

${ }_{94}^{94}$ Aejmelaeus 2012.
} 
figure of Paul tended to follow general trends, early Christian letter-writing in general was likely affected more by Paul's letters than the other way around.

\section{Bibliography}

Aejmelaeus, Anneli. 2012. "Pauline Heritage in 1 Peter: A Study of Literary Dependence in 1 Pet. 2:13-25”. Pages 125-147 in The Early Reception of Paul. Edited by Kenneth Liljeström. Publications of the Finnish Exegetical Society 99, Helsinki: The Finnish Exegetical Society. Barrett, Justin L. 1999. "Theological Correctness: Cognitive constraints and the study of religion." Method and Theory of the Study of Religion 11: 325-39

Braarvig, J. 1999. "Magic. Reconsidering the Grand Dichotomy”. Pages 21-54 in The World of Ancient Magic. Edited by D. R. Jordan, H. Montgomery and E. Thomassen. Papers from the First International Samson Eitrem Seminar at the Norwegian Institute at Athens, 4-8 May 1997, Bergen, Norwegian Institute at Athens.

Bremmer, Jan N. 2002a. "Magic in the Apocryphal Acts of the Apostles". Pages 51-70 in The Metamorphosis of Magic from Late Antiquity to the Early Modern Period. Edited by J. N. Bremmer and J. R. Veenstra. Leuven and Paris, Peeters.

Bremmer, Jan N. 2002b. "The Birth of the Term Magic". Pages 1-12 in The Metamorphosis of Magic from Late Antiquity to the Early Modern Period. Edited by J. N. Bremmer and J. R. Veenstra. Leuven and Paris, Peeters.

Cosmides, Leda \& John Tooby. 1994. "Beyond Intuition and Instinct Blindness: Toward an Evolutionarily Rigorous Cognitive Science." Cognition 50: 41-77.

Czachesz, István. 2007. "Magic and Mind: Toward a New Cognitive Theory of Magic, With Special Attention to the Canonical and Apocryphal Acts of the Apostles.". Pages 295-321 in Neues Testament und Magie: Verhältnisbestimmungen. Edited by T. Nicklas and Th. J. Kraus. Special issue of Annali di Storia dell'Esegesi 24.

Czachesz, István. 2011a. "Explaining Magic: Earliest Christianity as a Test Case.” Pages 141-165 in Past Minds: Studies in Cognitive Historiography. Edited by Luther H. Martin and Jesper Sørensen. London: Equinox. 
Czachesz, István. 2011b. "Women, Charity and Mobility in Early Christianity: Weak Links and the Historical Transformation of Religions.” Pages 129-154 in Changing Minds: Religion and Cognition through the Ages. Edited by István Czachesz and Tamás Biró. Leuven: Peeters.

Czachesz, István. 2014. “A Cognitive Perspective on Magic in the New Testament.” Pages 164-179 in Mind, Morality \& Magic. Edited by István Czachesz, and Risto Uro. London: Routledge.

Czachesz, István. 2017. “Comment 1: Morality, Networks, and Cultural Evolution: A Short Commentary on Petri Luomanen's 'Morality and the Evolution of Christianity."” Pages 198-206 in Christianity and the Roots of Morality: Philosophical, Early Christian, and Empirical Perspectives. Edited by Petri Luomanen, Anne Birgitta Pessi, and Ilkka Pyysiäinen. Leiden; Boston: Brill. Czachesz, István. 2019. "Magic". Pages 187-203 in The Oxford Handbook of Early Christian Ritual. Edited by Juliette Day, Richard de Maris, Rikard Roitto, and Risto Uro. Oxford: Oxford University Press.

Elliott, J. K. (ed.) 1993. The Apocryphal New Testament: A Collection of Apocryphal Christian Literature in an English Translation. Oxford: Oxford University Press.

Faraone, C. A. 1999. Ancient Greek Love Magic. Cambridge, Mass.: Harvard University Press. Gethin, Rupert. 2011. “Tales of Miraculous Teaching: Miracles in Early Indian Buddhism.” Pages 216-234 in The Cambridge Companion to Miracles. Cambridge University Press.

Iannaccone, Laurence R. 1992. "Sacrifice and Stigma: Reducing Free-riding in Cults, Communes, and Other Collectives.” Journal of Political Economy. Vol. 100, No. 2: 271-291.

Keil, F. C. 1979. Semantic and Conceptual Development: An Ontological Perspective. Cambridge, Mass.: Harvard University Press.

Khalidi, Tarif. 2009. Images of Muhammad: Narratives of the Prophet in Islam across the Centuries. New York: Doubleday.

Klauck, H.-J. 2008. Magic and Paganism in Early Christianity. The World of the Acts of the Apostles. Translated by B. McNeil. Edinburgh, T\&T Clark.

Koskenniemi, Erkki. 1998. “Apollonius of Tyana: A Typical Theios Aneer?” JBL 117/3: 455-467. Kuula, Kari. 2003. The Law, the Covenant and God's Plan. Volume 2. Paul's Treatment of the law and Israel in Romans. Publications of the Finnish Exegetical Society 85. Helsinki \& Göttingen: The Finnish Exegetical Society and Vandenhoeck \& Ruprecht. 
Lévi-Strauss, Claude. 1962. The Savage Mind. Letchworth: Garden City Press.

Lisdorf, Anders. 2007. The Dissemination of Divination in Roman Republican Times: A Cognitive Approach. Diss. University of Copenhagen.

Luomanen, Petri. 2013. "From Mark and Q to Matthew: An Experiment in Evolutionary Analysis." Pages 37-73 in Mark and Matthew II: Comparative Readings: Reception History, Cultural Hermeneutics, and Theology. Edited by E.-M. Becker \& A. Runesson. WUNT 304. Tübingen: Mohr Siebeck.

Mesoudi, Alex. 2011. Cultural Evolution: How Darwinian Theory Can Explain Human Culture \& Synthesize the Social Sciences. Chicago: Chicago University Press.

Meyer, Marvin. 2002. "The Prayer of Mary Who Dissolves Chains in Coptic Magic and Religion." Pages 407-415 in Magic and Ritual in the Ancient World. Edited by Paul Mirecki and Marvin Meyer. Leiden; Boston: Brill.

Moran, Laurence A. 2006. “What Is Evolution?” Retrieved May 14, 2020 from https://sandwalk.blogspot.com/2007/01/what-is-evolution.html

Pervo, Richard I. 2010. The Making of Paul: Constructions of the Apostle in Early Christianity. Minneapolis: Fortress Press.

Pervo, Richard I. 2014. The Acts of Paul: A New Translation with Introduction and Commentary. Eugene, Oregon: Cascade Books.

Pohjanheimo, Outi. 2014. "The Enrichment of Magical Thinking through Practices among Reiki Self-Healers.” Scripta Instituti Donneriani Aboensis, [S.1.] 24: 289-312.

Sax, W. 2010. "The Problem of Ritual Efficacy." Pages 3-16 in The Problem of Ritual Efficacy. Edited by J. Quack, W. S. Sax, and J. Weinhold. New York: Oxford University Press.

Scibilia, Anna. 2002. "Supernatural Assistance in Greek Magical Papyri." Pages 71-86 in The Metamorphosis of Magic from Late Antiquity to the Early Modern Period. Edited by J. N. Bremmer and J. R. Veenstra. Leuven and Paris, Peeters.

Sørensen, Jesper. 2013 "Magic Reconsidered: Towards a Scientifically Valid Concept of Magic.” Pages 229-242 in Defining Magic: A Reader. Edited by Otto Bernd-Christian, and Michael Stausberg. Sheffield: Equinox. 
Spittler, J. E. 2008. Animals in the Apocryphal Acts of the Apostles: The Wild Kingdom of Early Christian Literature. Tübingen: Mohr Siebeck.

Thomas, Christine M. 2003. The Acts of Peter, Gospel Literature, and the Ancient Novel: Rewriting the Past. Oxford; New York: Oxford University Press.

Ullucci, Daniel C. "What Did He Say?” Pages 21-31 in Religious Competition in the Third Century: Jews, Christians, and the Greco-Roman World. Edited by Jordan D. Rosenblum, Lily Vuong, and Nathaniel DesRosiers, Vandenhoeck \& Ruprecht. 